\title{
The influence of atmospheric circulation conditions on Betula and Alnus pollen concentrations in Wrocław, Poland
}

\author{
Hanna Ojrzyńska (D) Daria Bilińska • Małgorzata Werner • Maciej Kryza • \\ Małgorzata Malkiewicz
}

Received: 12 July 2019/Accepted: 4 February 2020/Published online: 12 February 2020

(C) The Author(s) 2020

\begin{abstract}
The influence of atmospheric circulation conditions on pollen concentrations of two taxons (Betula and Alnus) in Wroclaw, Poland, for the years 2005-2014 was analysed. Pollen concentration was analysed separately for twenty circulation types that were determined using objective classification. The results indicate the atmospheric circulation conditions favourable for both low and high pollen concentrations over Central Europe. Pollen concentrations vary significantly according to circulation types. The highest pollen concentrations for both taxons are typical for warm, sunny, and dry anticyclonic circulation types with anticyclone in the lower and upper troposphere, especially for types with advection from the SW. The lowest pollen concentrations are observed for cold, wet, and cloudy cyclonic types with advection from the northern sectors. There is also a positive and statistically significant trend in the frequency of circulation types favourable for high concentrations of Betula and Alnus.
\end{abstract}

H. Ojrzyńska ( $₫)$ · D. Bilińska · M. Werner · M. Kryza Department of Climatology and Atmosphere Protection, University of Wrocław, Kosiby 8, 51-621 Wrocław, Poland

e-mail: hanna.ojrzynska@uwr.edu.pl

\section{Malkiewicz}

Laboratory of Paleobotany, Department of Stratigraphical Geology, Institute of Geological Sciences, University of

Wrocław, Cybulskiego 30, 50-205 Wrocław, Poland
Keywords Pollen - Circulation types - Betula . Alnus $\cdot$ Central Europe

\section{Introduction}

According to the epidemiology of allergic diseases, on average $14.9 \%$ of Poles' show weakly positive reactions to birch pollen and almost $8.1 \%$ show allergy symptoms. In the case of alder, these numbers shrink to $11.1 \%$ and $4.6 \%$, respectively (Samoliński et al. 2014). Pollen grains constitute an important issue affecting human health because they induce allergenic diseases like asthma, rhinitis, and allergic conjunctivitis (Traidl-Hoffmann et al. 2003). The severity of symptoms increases as concentration of aeroallergens rises (Rapiejko et al. 2007). For the most part, the thresholds depend on the taxon, whereas different individuals may experience symptoms of varying severity for the same concentration level (Veriankaite et al. 2010). Relations between the clinical picture of allergic diseases and the level of pollen count in Poland have been studied by Rapiejko et al. (2007). Their study has shown that the first symptoms of the upper respiratory track in patients allergic to birch were visible during exposure to concentrations of 20 pollen $\mathrm{m}^{-3}$ (25\% of subjects were sensitized to birch pollen). Symptoms were noted in all the subjects sensitized to birch pollen at concentrations of approximately 75 pollen $\mathrm{m}^{-3}$, and at concentrations of 
120 pollen $\mathrm{m}^{-3}$, the symptoms were intensified. For the alder, these values were 45 pollen $\mathrm{m}^{-3}$ (first symptoms), 85 pollen $\mathrm{m}^{-3}$ (symptoms in all sensitized subjects), and 95 pollen $\mathrm{m}^{-3}$ (intensified symptoms), respectively.

Poland has been recognized as an area with large amounts of birch and alder pollen (Skjøth et al. 2013). According to Skjøth et al. (2008), the density of Betula sp. in broad-leaved forests ranges from 5 to $40 \%$ in lowland parts of the country and for Alnus sp. from 5 to $40 \%$ depending on the region.

The release of tree pollen is determined by several factors that include the time of the day, biological and meteorological parameters such as progress into the pollen season, temperature, relative humidity, and wind speed (Nowosad 2015). Both the initiation and magnitude of the daily pollen release mostly depend on daily temperatures. If certain thresholds are not met, then flowering will not be initiated. Similar dependencies are seen in many species, which means that small changes in temperature (such as $2{ }^{\circ} \mathrm{C}$ ) can have quite an impact on the daily flowering (Dosio and Paruolo 2011; Skjøth et al. 2015b). In general, during the Betula pollen season the temperature is higher than during the Alnus pollen season (Skjøth et al. 2015a). Puc and Kasprzyk (2013) have found a negative correlation between Alnus pollen concentration and relative humidity for most of the investigated seasons. Sofiev et al. (2013) have indicated a lower and upper limit of relative humidity for birch emissions at $50 \%$ and $80 \%$, respectively. They have also reported that even with a low wind speed but with a thermal convection being developed, turbulence is sufficient to release pollen from catkins. Strong wind stimulates the release of pollen but only to a certain threshold value. If the wind speed exceeds $5 \mathrm{~m} \mathrm{~s}^{-1}$, it no longer influences the rate of pollen release because it is limited by the amount of pollen grains in catkins prepared to release (Sofiev et al. 2013). Menut et al. (2014) found that temperature, precipitation rate, and specific humidity are significantly correlated with the measured pollen concentrations. Correlations between meteorological factors and pollen concentrations in Poland have been investigated (e.g. Weryszko-Chmielewska et al. 2006; Myszkowska and Piotrowicz 2009; Grewling et al. 2012; Malkiewicz et al. 2014; Nowosad et al. 2015; Puc et al. 2015). They also found that meteorological factors have an enormous influence on pollen concentration.
A connection between pollen concentrations and atmospheric fronts has been reported by GoyettePernot et al. (2003) and Nowosad et al. (2015). Nowosad et al. (2015) have shown a strong correlation between temporal variations in Alnus, Betula, and Corylus pollen counts in Poland on the one hand and air mass exchange on the other. They suggested that between 30 and $40 \%$ of variability in pollen counts is related to the passage of a single weather front. Goyette-Pernot et al. (2003) have reported that passage of fronts often increases the occurrence of regional scale ragweed pollen peaks in the city of Montreal. They have also shown that anticyclonic conditions are favourable for local pollen production but inhibit dilution on larger scales. Grundström et al. (2017) have found the approach based on weather types to be a relatively simple method for characterizing the weather condition in a synoptic scale, thereby grouping together many meteorological variables that are important for processes that determine the high or low levels of pollen concentration. Conducted in Gothenburg and Malmö, their study indicated that high birch pollen concentrations are correlated with dry and moderately calm conditions during an anticyclone and weather types with NE, SE, and S geostrophic wind direction, whereas the lowest concentration levels were found in wet and windy types with direction from SW, W, and NW and for the cyclonic type (Grundström et al. 2017). The number of studies that applied weather types for pollen analysis is rather limited, and according to the authors, it has yet to be done for Central Europe.

Long-range transport is another important factor responsible for atmospheric pollen concentrations. The transport of pollen from the south of Europe is especially visible in periods before the local pollen season starts in Central and Northern Europe (Ranta et al. 2006; Skjøth et al. 2007). Source regions of various pollens have been determined with the use of back trajectory from the HYSPLIT model (Makra et al. 2010; Hernández-Ceballos et al. 2014; de Weger et al. 2016; Bilińska et al. 2017). However, examples from Poland show that long-range transport plays a significant role in the concentrations of pollen that are rare in the Polish environment, especially Ambrosia (Stach et al. 2007; Smith et al. 2008; Kasprzyk et al. 2011; Bilińska et al. 2017). Concentrations of species native to Poland are mainly influenced by local sources but appear to be augmented by remote sources, 
particularly for Betula (Bogawski et al. 2019), though only to a small degree for Alnus (Skjøth et al. 2015a).

The purpose of this study is to analyse how the atmospheric circulation affects pollen concentrations of Betula and Alnus in Wrocław, southwest Poland, with the use of automatic classification of air circulation types. The circulation conditions favourable for low and high pollen concentrations were determined, after which the circulation types that might lead to the risk of pollen concentrations exceeding the threshold values were identified. The main tested hypothesis is the following: a high concentration of birch and alder pollen occurs during the same circulation types with upper anticyclonic vorticity and high temperature, sunshine, and vapour pressure deficit.

Furthermore, the long-term trend in the frequency of types favourable to high pollen concentrations is analysed so as to ascertain whether the observed climate changes increase the risk of above-threshold episodes for Betula and Alnus.

\section{Materials and methods}

\subsection{Study area}

Wrocław is located on the bank of the Odra River in the Lower Silesia region in the southwestern part of Poland. The climate of Wrocław is temperate with transition due to the influence of maritime and continental air masses. The climatic conditions are formed mainly by the Icelandic Low and Azores High and seasonal by the Asiatic High and South-Asiatic Low. The mean annual temperature reaches $8.7^{\circ} \mathrm{C}$ (1971-2000) with minimum in January $\left(-0.9^{\circ} \mathrm{C}\right)$ and maximum in July $\left(18.1^{\circ} \mathrm{C}\right)$. The annual precipitation sum is almost $570 \mathrm{~mm}$ on 157 days with precipitation. The highest monthly sum of precipitation is observed in July $(90.8 \mathrm{~mm})$ and the lowest in February $(24.1 \mathrm{~mm})$. The growing season lasts 228 days (Głowicki et al. 2005).

According to the lexicon of the greenery of Wrocław (Bińkowska et al. 2013), the dominant species in the city of the Betula type is Betula pendula, but also present are individual specimens of Betula papyrifera, Betula pubescens, and Betula utilis. Under this reference, the dominant species for Wrocław's Alnus type is Alnus glutinosa.

\subsection{Pollen data}

The daily airborne alder and birch pollen concentration data represent the 10-year period from 2005 to 2014. We calculated the pollen concentration based on pollens gathered at the Wrocław station $(51.1164 \mathrm{~N}$, 17.0278E) with a Burkard 7-day volumetric pollen trap. The sampler is located on the roof of the building at a height of $20 \mathrm{~m}$ above ground level near the centre of the city. The sampling site is surrounded by a dense urban build-up area and small patches of greenery. To the north of the building grow small birches and several horse-chestnut trees and to the south of the building is an alley of plane trees (Malkiewicz et al. 2014).

Pollen grains were counted under a light microscope with 400 magnification along four longitudinal transects. The results were expressed as the number of pollen grains per cubic metre of air, i.e. as a daily mean value (pollen $\mathrm{m}^{-3}$ ) (Malkiewicz et al. 2014). Airborne pollen is counted following the recommendations of the International Association for Aerobiology (Galán et al. 2014). The seasonal pollen's characteristics were counted using the $95 \%$ method.

The number of days with pollen concentration exceeding the threshold values for the occurrence of allergic reactions was counted for each circulation type. We used the threshold values of 85 pollen $\mathrm{m}^{-3}$ for Alnus and 75 pollen $\mathrm{m}^{-3}$ for Betula (Rapiejko et al. 2007; Bergmann et al. 2008), which indicate that allergy symptoms have been noted in all sensitized subjects.

\subsection{Meteorological data}

The daily data of meteorological elements were taken from Wrocław Strachowice Airport's measuring station $(51.1 \mathrm{~N}, 16.883 \mathrm{E})$ of the Institute of Meteorology and Water Management-National Research Institute. Data comprising air temperature, sunshine duration, amount of precipitation, vapour pressure, relative humidity, fog duration, wind speed, and pressure were used. The vapour pressure deficit was calculated with the use of vapour pressure and relative humidity data following Teten's formula (Campbell and Norman 1998). The meteorological data were used to present the average meteorological conditions during each circulation type. Additionally, the meteorological factors described below were prepared for the sake 
of ascertaining if there is a difference between pollen concentrations in specific circulation types when the values of meteorological elements are higher or lower than their appropriate means. The use of meteorological factors was connected with the assumption of a multifactor ANOVA.

The mean values of the analysed meteorological elements were calculated for each of the twenty defined circulation types. Based on those means, the meteorological factors for each day and elements were calculated. The factors received a value of 1 when the daily value of a particular meteorological element was greater than the adequate meteorological mean, and 0 if it was less than the mean. The meaning of the factors of temperature is as follows: 1- "warm", 0- "cold"; for sunshine duration 1-“sunny", 0- "cloudy"; for vapour pressure deficit 1-“dry", 0- "wet”; for relative humidity 1-“wet", 0-“dry"; for wind factor 1-“windy", 0-“calmly"; and for pressure 1-"high", 0- "low". Only the fog and precipitation factors were specified as 1 when the phenomenon occurred and 0 when it did not.

\subsection{Circulation types}

Air circulation types were determined for each day of the pollen seasons (February-May) for the years 1948-2017 according to a simplified methodology of automatic classification developed for the Lower Silesia region (Ojrzyńska 2015; Ojrzyńska et al. 2017). Twenty types of circulation were analysed. The name of each circulation type is built according to the scheme: $\mathrm{AABB}$, where AA corresponds to the direction of advection (SW-southwest, NW-northwest, SE-southeast, NE—northeast, XX-indeterminate direction). $\mathrm{BB}$ describes the type of lower and upper vorticity (CC-lower and upper cyclonic, $\mathrm{CA}-$ lower cyclonic, upper anticyclonic, AA-lower and upper anticyclonic, AC-lower anticyclonic, upper cyclonic). In this study, we have not used the classification of "wet" and "dry" circulation types because the main classification factor-precipitable water-describes the water content in a whole column of troposphere. This information cannot be directly converted to vapour pressure near the surface and therefore cannot be linked directly with pollen emission.

All criteria of circulation types' classification were determined with the use of gridded meteorological data $\left(2.5^{\circ} \times 2.5^{\circ}\right.$ spatial resolution, 24-h temporal resolution) from NCEP/NCAR reanalysis (Kalnay et al. 1996). The data were interpolated with the use of spline function in the area of southwestern Poland to a spatial resolution of $5 \mathrm{~km} \times 5 \mathrm{~km}$. Classification of circulation types was done for each grid cell separately. To determine the circulation type for each individual day, the prevailing type was calculated by applying the mode function for all the $5 \mathrm{~km} \times 5 \mathrm{~km}$ grid cells. This was done separately for the direction of advection and vorticity. Direction of advection is classified on the basis of wind direction from the $700 \mathrm{hPa}$ isobaric level, if wind speed exceeds $2 \mathrm{~m} \mathrm{~s}^{-1}$. In situations with a wind speed of lower than $2 \mathrm{~m} \mathrm{~s}^{-1}$ or when no prevailing wind direction is determined, the XX type is noted. Types of vorticity are calculated based on geopotential values from the $850 \mathrm{hPa}$ (lower vorticity) and $500 \mathrm{hPa}$ (upper vorticity) isobaric levels by means of the formula $\nabla^{2} \phi$, where $\nabla$ is the nabla operator and $\phi$ is the geopotential value. A positive value of $\nabla^{2} \phi$ is classified for the cyclonic type, and a negative one for the anticyclonic type.

\subsection{Statistical analysis}

The analysis has three steps. First, we look for the relations between pollen concentrations and circulation types with frequency above $4 \%$ in the analysed pollen seasons. Second, we focus on relations between the pollen concentrations and specific meteorological elements, as measured at weather station in Wrocław. Finally, we look for possible combinations of these effects using the multi-factor analysis of variance.

The relations between circulation types, meteorological elements, and pollen concentrations during the pollen seasons were analysed separately for each taxon with the use of $\mathrm{R}$ software for statistical computing ( $\mathrm{R}$ Core Team 2014) with packages: cor, nortest, tidyverse, and corrplot. For the pollen seasons of each taxon, the circulation types with the highest means of pollen concentration were selected. The number of days with pollen concentration exceeding the threshold values for the occurrence of allergic reactions (Alnus $\geq 85$ pollen $\mathrm{m}^{-3}$, Betula $\geq 75$ pollen $\mathrm{m}^{-3}$; Rapiejko et al. 2007; Bergmann et al. 2008) was counted for each circulation type.

To check whether there is any influence of circulation types on pollen concentration, the correlation 
between the seasonal pollen integral (SPIn) in the years that followed and the frequencies of particular circulation types was calculated with the use of the Pearson coefficient of determination (confidence level $=0.95$ ). Correlation analysis was also carried out to quantify the relation between pollen concentration and meteorological elements on the one hand and pollen seasonal length in the entire analysed period on the other.

Because of the qualitative characteristic of circulation types' data, the diversity of pollen concentrations in circulation types was analysed with the use of an analysis of variance (ANOVA). To determine whether meteorological conditions influence pollen concentration independently or jointly with circulation types, the multifactor ANOVA was used. The assumption of normality of pollen data was almost fulfilled after applying log transformation. According to Glass et al. (1972) and Lix et al. (1996), ANOVA is not very sensitive to moderate deviations from normality. The homogeneity of data variance was checked with the use of Levene's test.

The analysis of the circulation types' frequency trends has been done for the last 70 years (1948-2017) to ascertain whether there is any tendency of occurrence among the circulation types favourable to high pollen concentration. The Mann-Kendall test for monotonic trend was carried out, and Sen's slope estimator was calculated with the use of R software for statistical computing. The analysis concerned potentially the entire pollen season and the particular months for Alnus (February-April) and Betula (AprilMay).

\section{Results}

\subsection{Characteristic of circulation types during the pollen seasons}

For SW Poland and Wrocław, the pollen season covers mainly February-April for Alnus and April-May for Betula (Tables 1,2). For the years being analysed, no overlap between pollen seasons for Alnus and Betula was observed. The average seasonal pollen integral reaches 3562 pollen $\mathrm{m}^{-3}$ for Alnus, whereas 8570 pollen $\mathrm{m}^{-3}$ for Betula with the average length of the pollen season equalling 31 and 22 days, respectively. Alnus has a more diverse pollen seasonal length (standard deviation reached almost 13 days for Alnus and 5 days for Betula), whereas Betula has a more differentiated SPIn than Alnus. For both taxons, the daily maximum concentration in the analysed seasons reached almost $30 \%$ of the average SPIn.

There is no statistically significant correlation between the length of the pollen season and SPIn for both Alnus and Betula. Significant correlations are noted for both analysed taxons in terms of SPIn and frequency of specified circulation types. A negative correlation concerns the Alnus pollen season between SPIn and the frequency of lower and upper cyclonic type NWCC ( -0.73$)$. For Betula, a positive correlation between SPIn and the frequency of types with lower anticyclone is observed: NEAC (0.70) and SWAC (0.70; Table 3).

The frequencies of circulation types during the analysed pollen seasons are summarized in Fig. 1. The lower and upper anticyclonic types with advection from NE, NW, and SW are dominant. For the Alnus pollen seasons, a relatively high frequency is observed for lower and upper cyclonic types from SW. For the Betula pollen seasons, there is increased frequency of NE types. Other circulation types occur less often than 7\% (17 days for Alnus and 14 for Betula in 10 pollen seasons; usually 1-2 days for each pollen season). Regardless of the specific circulation types, the contribution of days with high pollen concentration (Alnus $\geq 85$ pollen $\mathrm{m}^{-3}, \quad$ Betula $\geq 75$ pollen $\mathrm{m}^{-3}$ ) to the whole number of days in the analysed period is higher for Betula than for Alnus. A high contribution of days with high Betula pollen concentrations is observed in the most frequent anticyclonic types (NEAA, NWAA, SWAA) and in types with advection from the SW (SWCC, SWCA, SWAC). For Alnus, the contribution of days with high pollen concentration exceeding the value of $50 \%$ is observed only for the SWAA type.

The specific circulation types represent different combinations of meteorological conditions (Fig. 2). For the Alnus pollen season, the highest average temperatures and the longest sunshine duration with high vapour pressure deficit and low amount of precipitation as well as low wind speed are noted for the lower and upper anticyclonic types SEAA, SWAA, and partly for NEAA. Similar conditions for Betula are observed partly for the type SWAA. The coldest and cloudiest types with a low average vapour pressure deficit and average precipitation above $1.2 \mathrm{~mm}$ as well 
Table 1 Basic characteristics of Alnus pollen seasons

\begin{tabular}{lllll}
\hline Year & Day of season start & Length of the season & Seasonal pollen integral (SPIn) & Maximum pollen concentration \\
\hline 2005 & 17.03 & 19 & 5024 & 1034 \\
2006 & 27.03 & 14 & 3737 & 881 \\
2007 & 03.02 & 52 & 1019 & 189 \\
2008 & 25.01 & 38 & 5731 & 484 \\
2009 & 03.03 & 34 & 1234 & 204 \\
2010 & 17.03 & 13 & 3750 & 987 \\
2011 & 26.02 & 33 & 3124 & 730 \\
2012 & 1.03 & 28 & 2902 & 532 \\
2013 & 05.03 & 48 & 4695 & 881 \\
2014 & 10.02 & 33 & 4402 & 785 \\
\hline
\end{tabular}

Table 2 Basic characteristics of Betula pollen seasons

\begin{tabular}{lllrl}
\hline Year & Day of season start & Length of the season & Seasonal pollen integral (SPIn) & Maximum pollen concentration \\
\hline 2005 & 12.04 & 19 & 4849 & 1626 \\
2006 & 19.04 & 21 & 15,373 & 2368 \\
2007 & 07.04 & 20 & 4445 & 1322 \\
2008 & 09.04 & 27 & 9751 & 1452 \\
2009 & 07.04 & 20 & 3802 & 1317 \\
2010 & 09.04 & 22 & 9348 & 1779 \\
2011 & 05.04 & 25 & 4481 & 843 \\
2012 & 04.04 & 28 & 14,924 & 1807 \\
2013 & 19.04 & 12 & 5584 & 2247 \\
2014 & 30.03 & 27 & 13,141 & 278 \\
\hline
\end{tabular}

as the highest wind speed are types SWCC and SWCA for both taxons and additionally NWCC for Alnus. Regardless of the taxon, types with lower anticyclone and upper cyclone are mostly colder and drier than types with lower cyclone and upper anticyclone even though the average sunshine duration in the former group is more often higher.

\subsection{Pollen concentration in particular circulation types}

The Alnus pollen concentration according to the circulation types is presented in Fig. 3. The highest median value of pollen concentration (nearly 200 pollen $\mathrm{m}^{-3}$ ) is observed for SWAA. For SWAA, the pollen concentration exceeds 300 pollen $\mathrm{m}^{-3}$ in $25 \%$ of days and in some cases reaches almost 1000 pollen $\mathrm{m}^{-3}$. Very high concentrations are also noted for the lower and upper anticyclonic types with advection from $\mathrm{NE}$ and a maximum value 1034 pollen $\mathrm{m}^{-3}$ as well as for SWCC, SWCA, and NWAC; however, these are rare and do not influence the median significantly. High Alnus pollen concentrations, exceeding the threshold value of 85 pollen $\mathrm{m}^{-3}$, are observed for all circulation types except for the lower and upper cyclonic NWCC. The variability in mean concentration of Alnus in specific circulation types is high within a range of nearly 0 pollen $\mathrm{m}^{-3}$ for NWCC to ca. 200 pollen $\mathrm{m}^{-3}$ for SWAA (Fig. 4). For most types, the mean concentration varies from 50 to 130 pollen $\mathrm{m}^{-3}$. 
Table 3 Pearson's correlation coefficients for SPIn and frequency of particular circulation types

Significant correlations $(\alpha<0.05)$ are shown in bold

The highest mean and median values of Betula pollen concentration are observed in similar types for Alnus as well (Figs. 3, 4, 5, 6). In circulation type SWAA, the median values exceed 500 pollen $\mathrm{m}^{-3}$. The highest single concentrations exceeding 1500 pollen $\mathrm{m}^{-3}$ are noted mainly for types with lower and upper anticyclone (NEAA, NWAA, SWAA) and lower cyclone, upper anticyclone (SECA, SWCA-with maximum 2368 pollen $\mathrm{m}^{-3}$ ). For all circulation types, the median values of Betula pollen

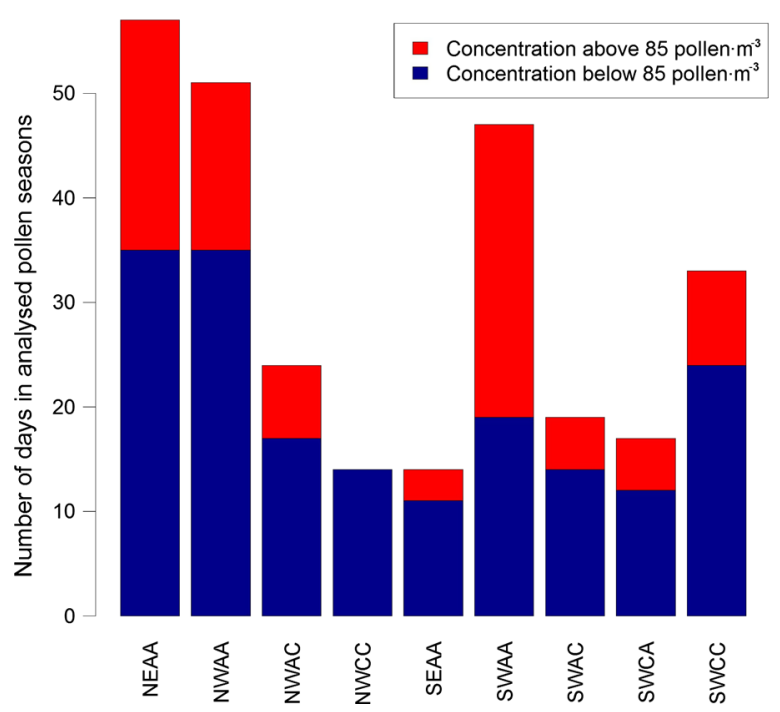

Fig. 1 Frequency of circulation types for Alnus (left side) and Betula (right side) pollen seasons and contribution of days with high pollen concentrations (Alnus $\geq 85$ pollen $\mathrm{m}^{-3}$, concentration exceed the allergic symptoms threshold value. The mean pollen concentration for most types reaches from 200 to 450 pollen $\mathrm{m}^{-3}$ (Fig. 6). The lowest mean (under 100 pollen $\mathrm{m}^{-3}$ ) concerns the NWAC circulation type.

The variability of both Alnus and Betula mean pollen concentrations in days with specified conditions described by meteorological daily factors of temperature, sunshine duration, fog, precipitation, vapour pressure deficit, relative humidity, wind, and pressure is analysed and presented in Figs. 4 and 6. The highest differences in the mean pollen concentrations concern days with various temperature and vapour pressure deficit factors. Noticeable effects are observed for the sunshine duration factor, the relative humidity factor, and for the Betula atmospheric pressure factor as well. The differences in mean pollen concentrations between "cold" and "warm" days and "wet" and "dry" days reach almost 90 pollen $\mathrm{m}^{-3}$ for Alnus and 200 pollen $\mathrm{m}^{-3}$ for Betula, whereas in particular circulation types the differences are even higher (Fig. 7). The correlations between pollen concentration and temperature, and between pollen concentration and vapour pressure deficit are positive for both taxons, except that those for Alnus are slightly higher than for Betula (Fig. 8). For Betula low positive correlation was also noted between pollen concentration and sunshine duration, whereas there was also a

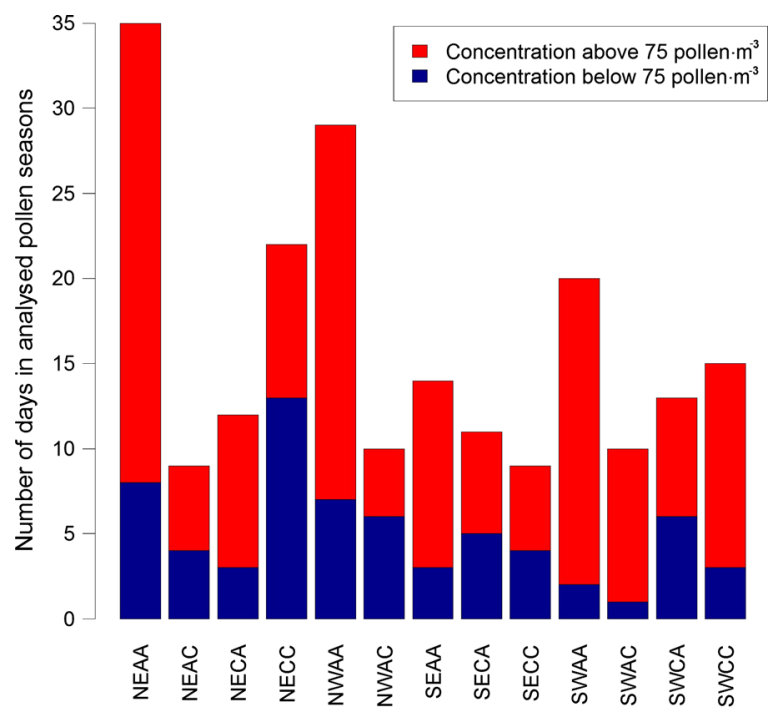

Betula $\geq 75$ pollen $\mathrm{m}^{-3}$ ). Frequency is calculated from 10 analysed pollen seasons. Circulation types with frequency below $4 \%$ were omitted 
Fig. 2 Meteorological conditions of circulation types for Alnus $(\mathbf{a}, \mathbf{b})$ and Betula $(\mathbf{c}, \mathbf{d})$ : average values of sunshine duration, temperature, vapour pressure deficit $(d)$, amount of precipitation $(R)$, pressure, wind speed, and relative humidity $(f)$ in specific circulation types. Threshold values of vapour pressure deficit, amount of precipitation, and relative humidity are the mean values from all days in 10 pollen seasons
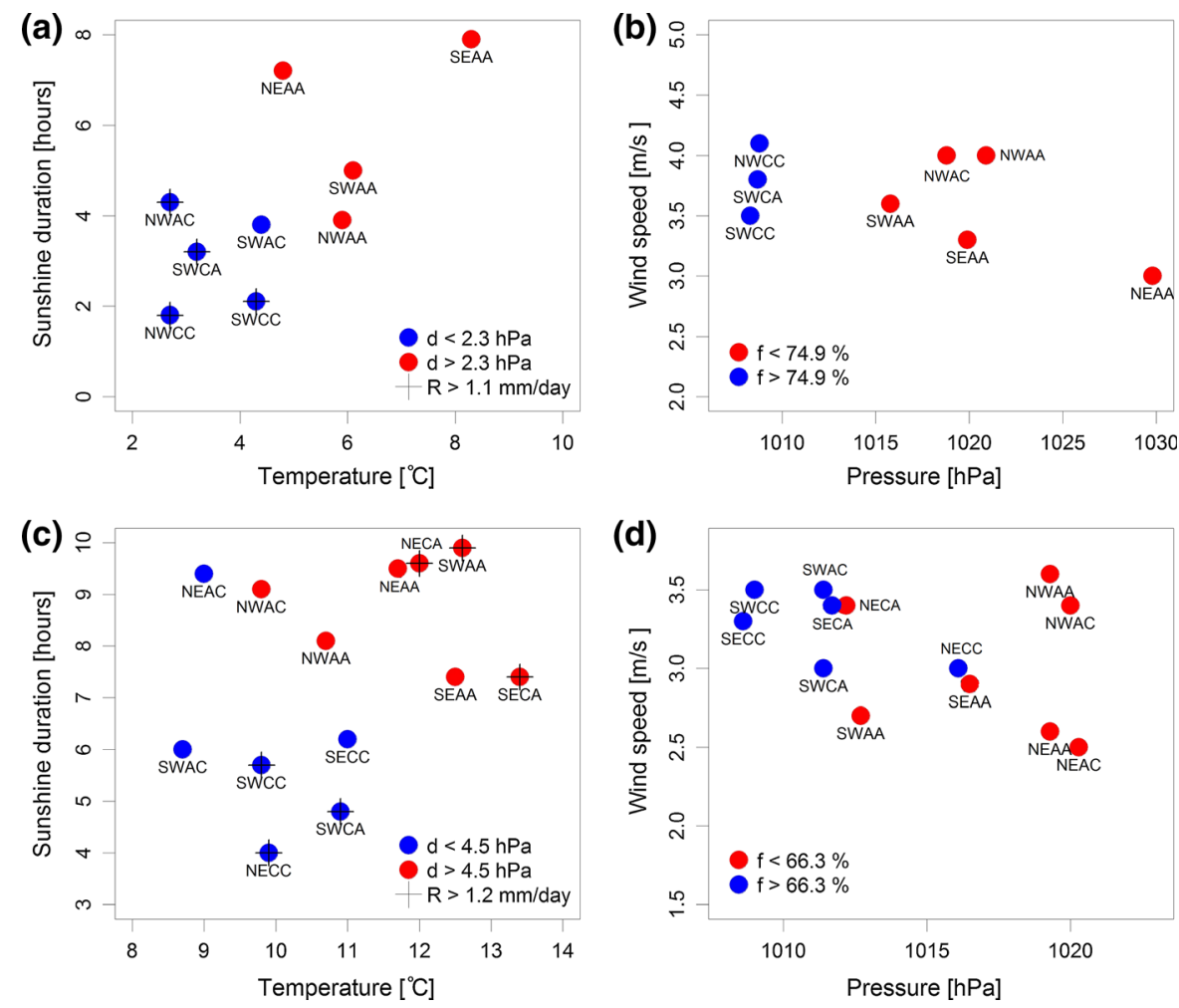

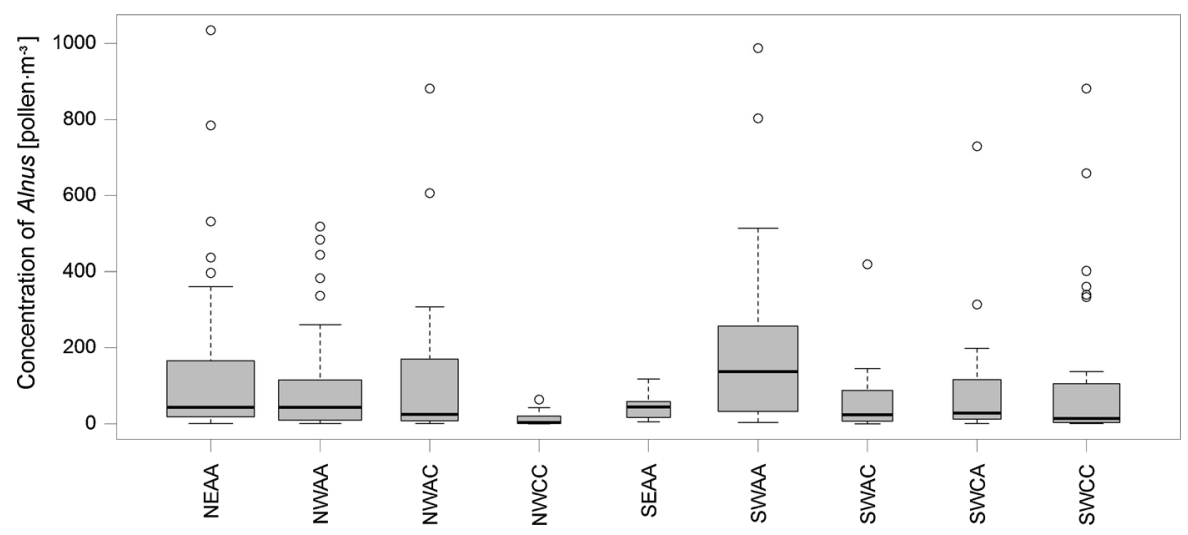

Fig. 3 Alnus pollen concentration (pollen $\mathrm{m}^{-3}$ ) in circulation types with frequency $>4 \%$ in the analysed pollen seasons; boxplots width is proportional to the frequency of circulation types; hinges show the first and third quartiles, the whiskers are

negative correlation between pollen concentration and precipitation and between pollen concentration and atmospheric pressure.

The results of ANOVA largely support the findings described above. The differences between pollen concentrations are considerable in particular circulation types; however, the same circulation types may
1.5 times the spread of hinges or data extreme (if $1.5 *$ the hinge spread is smaller than the extreme value), and circles are the outliers, which are above/below 1.5 times the box length

vary depending on temperature and sunshine duration, just as in days with specific temperature factor or sunshine duration factor for both Alnus and Betula (Table 4). Additionally, for Betula the precipitation factor is also a significant contributor. A combination of several factors is also important for pollen concentrations. For both taxons, this includes various 


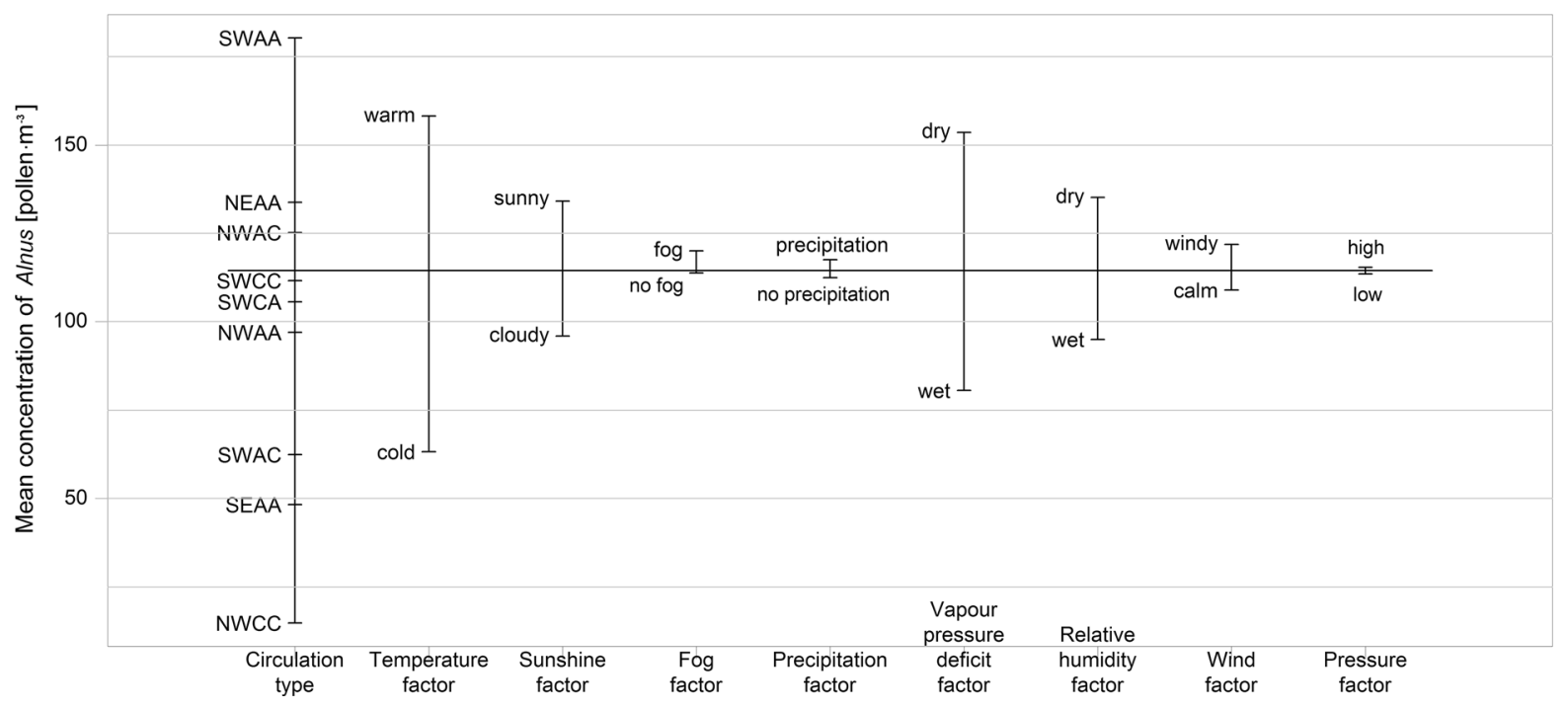

Fig. 4 Mean concentration of Alnus (pollen $\mathrm{m}^{-3}$ ) in particular circulation types and days with various meteorological factors. Bold horizontal lines represent the mean concentration of Alnus for all analysed pollen seasons

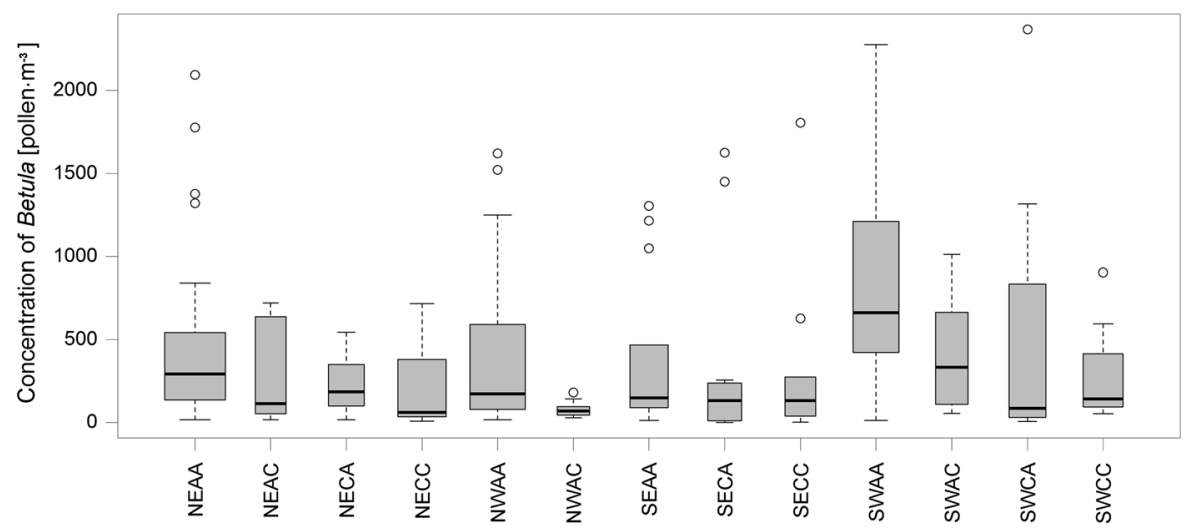

Fig. 5 Betula pollen concentration (pollen $\mathrm{m}^{-3}$ ) in circulation types with frequency $>4 \%$; boxplots' width is proportional to the circulation types' frequency; the boxplot hinges show the first and third quartiles, the whiskers are 1.5 times the spread of

circulation types with the sunshine duration factor, and for Alnus also various circulation types with the temperature factor (Table 4).

\subsection{Trend analysis of circulation types' frequency}

For the last 70 years (1948-2017), weak but statistically significant trends of selected circulation types' occurrence have been noted for circulation types specific for high pollen concentrations. For the Alnus pollen season (February-April) and Betula pollen season (April-May), the frequency of groups of lower hinges or data extreme (if $1.5 *$ the hinge spread is smaller than the extreme value), and circles are the outliers, which are above/below 1.5 times the box length

and upper anticyclone types (AA) increases by 1 day per 10 years (Fig. 9). A statistically significant positive trend is calculated for the NWAA type in March, i.e. in the middle of a potential Alnus pollen season. The same is for NWAA and SWAA in May, which is important for Betula (Fig. 10). In May, a significant decrease concerns the SWCC circulation type (Fig. 10), whereas throughout the whole Betula pollen season a negative trend is noted in the SECA type. No circulation type shows any statistically significant trend for February and April. 


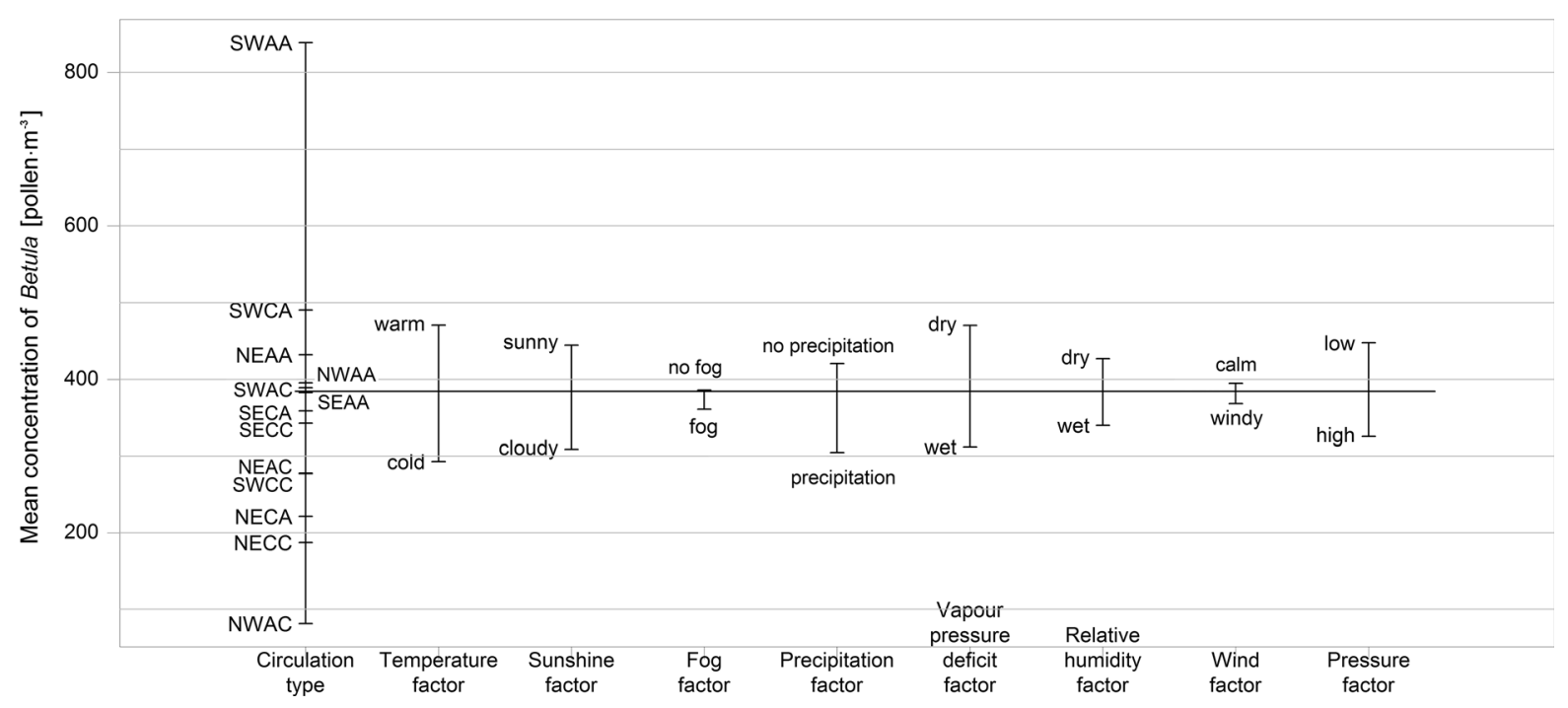

Fig. 6 The mean concentration of Betula (pollen $\mathrm{m}^{-3}$ ) in particular circulation types and days with various meteorological factors. Bold horizontal lines represent the mean concentration of Betula in the entire ten pollen seasons

\section{Discussion}

In this paper, we have described the relations between Alnus and Betula pollen concentrations on the one hand and atmospheric circulation types on the other, based on data from 10 pollen seasons gathered at Wroclaw, SW Poland. The atmospheric circulation types specified from information about the direction of air masses' advection as well as lower and upper vorticity are characterized by different meteorological elements. This complex description of weather conditions made it possible to analyse the influence of meteorology on pollen concentration and determine the circulation types with the highest and lowest pollen concentration. This approach was used earlier by Grundström et al. (2017) for birch in Gothenburg and Malmö. Our results show that, similar to the Swedish study, the highest pollen concentrations for Betula and Alnus are noted for warm, sunny, and dry anticyclonic circulation types, especially when the anticyclone vorticity concerns the lower and upper troposphere. Regardless of the pollen taxon, the most favourable conditions for high pollen concentration are observed for type SWAA. The important role of the upper anticyclone in raising the level of pollen concentrations in the aforementioned circulation types is connected with the descent of air masses. These conditions inhibit the dilution of pollen on larger scales (Goyette-Pernot et al. 2003).
The lowest pollen concentration concerns cold, wet, and cloudy cyclonic types: SWCC, NWCC, and NWAC. Contrary to Grundström et al. (2017) in terms of birch in Sweden, the pollen concentrations of Betula and Alnus in Wrocław are to a small extent influenced by wind speed. However, this is difficult to surmise, as the frequency of circulation types with calm wind conditions (especially from XX group of circulation types) favourable to pollen accumulation is very low (below the threshold frequency of $4 \%$ in pollen seasons). High pollen concentrations of both analysed taxons are observed regardless of the direction of air masses' advection. It confirms the role of local pollen sources, as described by Skjøth et al. (2015a).

The results of a multifactor analysis of ANOVA confirm the influence of the air temperature and sunshine duration on pollen release and atmospheric concentration pollination. Faegri and Iversen (1989) as well as Pacini and Hesse (2004) have underlined vapour pressure deficit as the most important meteorological element in the formation of pollen concentration; however, temperature and sunshine duration have a strong correlation with it. In this work, a significant differentiation in pollen concentrations between specified circulation types with various meteorological conditions has been corroborated. Additionally, it is also shown that the influence of sunshine duration on both taxons has diversified the 

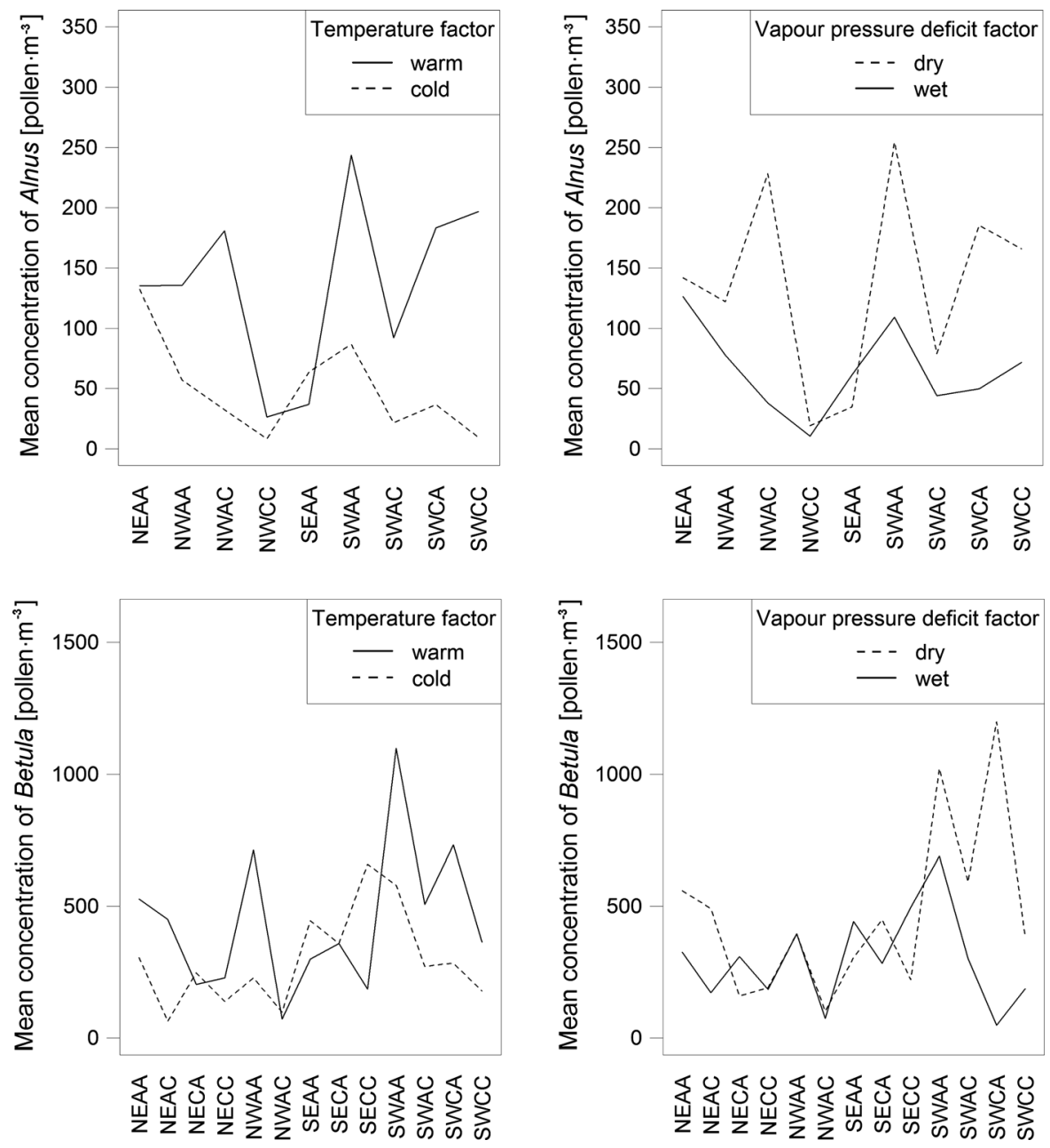

Fig. 7 The mean concentration of Alnus and Betula $\left(\right.$ pollen $\mathrm{m}^{-3}$ ) in circulation types and days with various temperature factors and vapour pressure deficit factors

pollen concentration in days with specific circulation types. Regardless of taxon being analysed, in sunny days pollen concentrations are higher than in cloudy days in most of the circulation types. For Alnus and Betula, the enormous difference in pollen concentration is connected especially with type SWCA and for Betula also SEAA and SWAC.

Significant correlations between SPIn and the frequency of selected circulation types show that current meteorological conditions during the pollen season affect not only the daily pollen concentration but also the overall SPIn. The aforementioned correlation is negative and pertains to the cold, wet, and cloudy type NWCC for Alnus, whereas for Betula it is positive and connected with warmer and more dry types with lower anticyclone (NEAC and SWAC). The correlation for birch is visible despite its biennial cycle in SPIn (Grewling et al. 2012; Kubik-Komar et al. 2019; Tseng et al. 2020). Factors recorded during buds' formation (especially a year before flowering) are mentioned as the most important in SPIn modelling (Dahl and Strandhede 1996; Grewling et al. 2012; Ritenberga et al. 2018). The results of this work allow for the view that including the expected frequency of circulation types may improve the modelling of pollen season's intensity.

The results of trend analysis for the frequency of circulation types correspond to earlier conclusions about changes in the air circulation frequency for East and Central Europe presented by Bartoszek (2017) for 


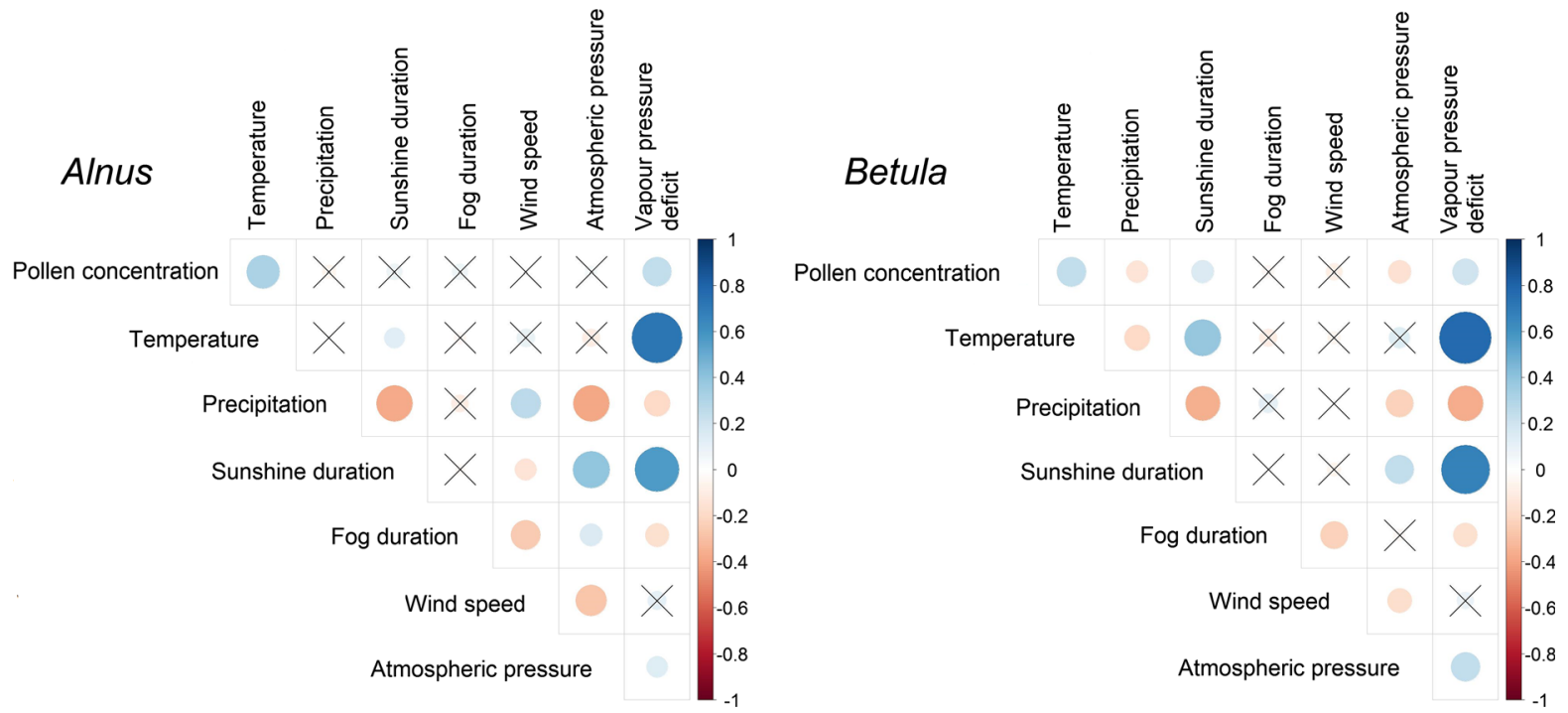

Fig. 8 The correlation table between pollen concentration and meteorological factors for Alnus and Betula; significance level-0.05, $\mathrm{X}$-statistically insignificant

Table 4 The results of multifactor analysis of variance ANOVA - the factors with significant pollen concentration of Alnus and Betula

Significance codes: 0 '**** 0.001 '**' 0.01 '*’ 0.05

\begin{tabular}{lll}
\hline Taxon & Factors & Significance \\
\hline Alnus & Circulation type & $* * *$ \\
& Temperature factor & $* * *$ \\
& Sunshine duration factor & $* * *$ \\
& Circulation type + sunshine duration factor & $*$ \\
& Circulation type + temperature factor & $*$ \\
Betula & Circulation type & $* * *$ \\
& Temperature factor & $* *$ \\
& Sunshine duration factor & $*$ \\
& Precipitation factor & $*$ \\
& Circulation type + sunshine duration factor & $* *$ \\
\hline
\end{tabular}
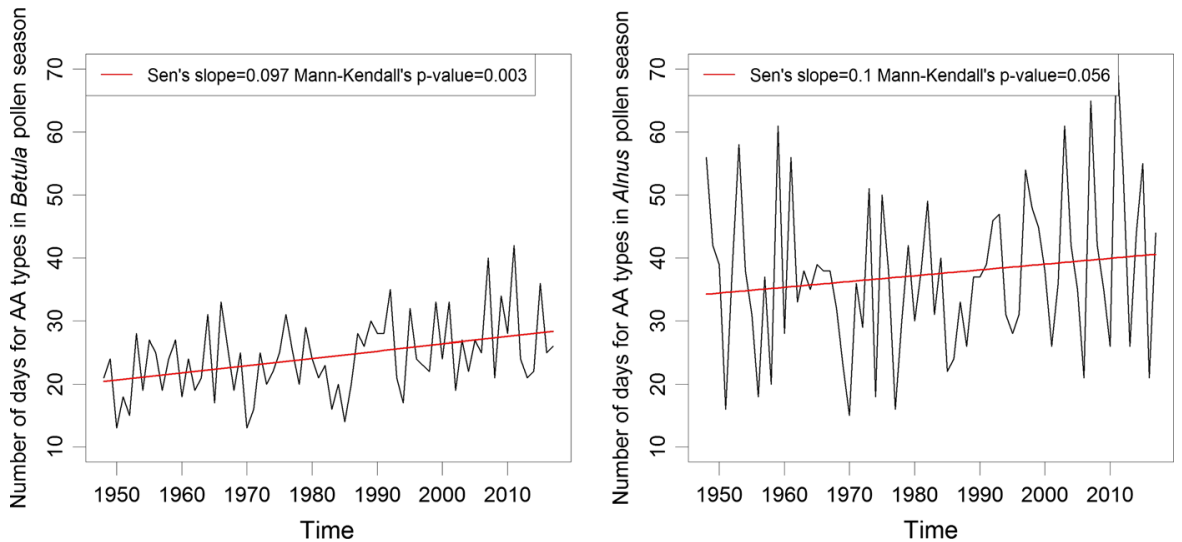

Fig. 9 Number of days for lower and upper anticyclonic (AA) types during the pollen season for Betula (April-May) and Alnus (February-April) for the period 1948-2017. Trend line is in red 
Fig. 10 Number of days for the NWAA type in March (upper left), NWAA in May (upper right), SWAA in May (bottom left), and SWCC in May (bottom right) for the period 1948-2017. Trend line is in red
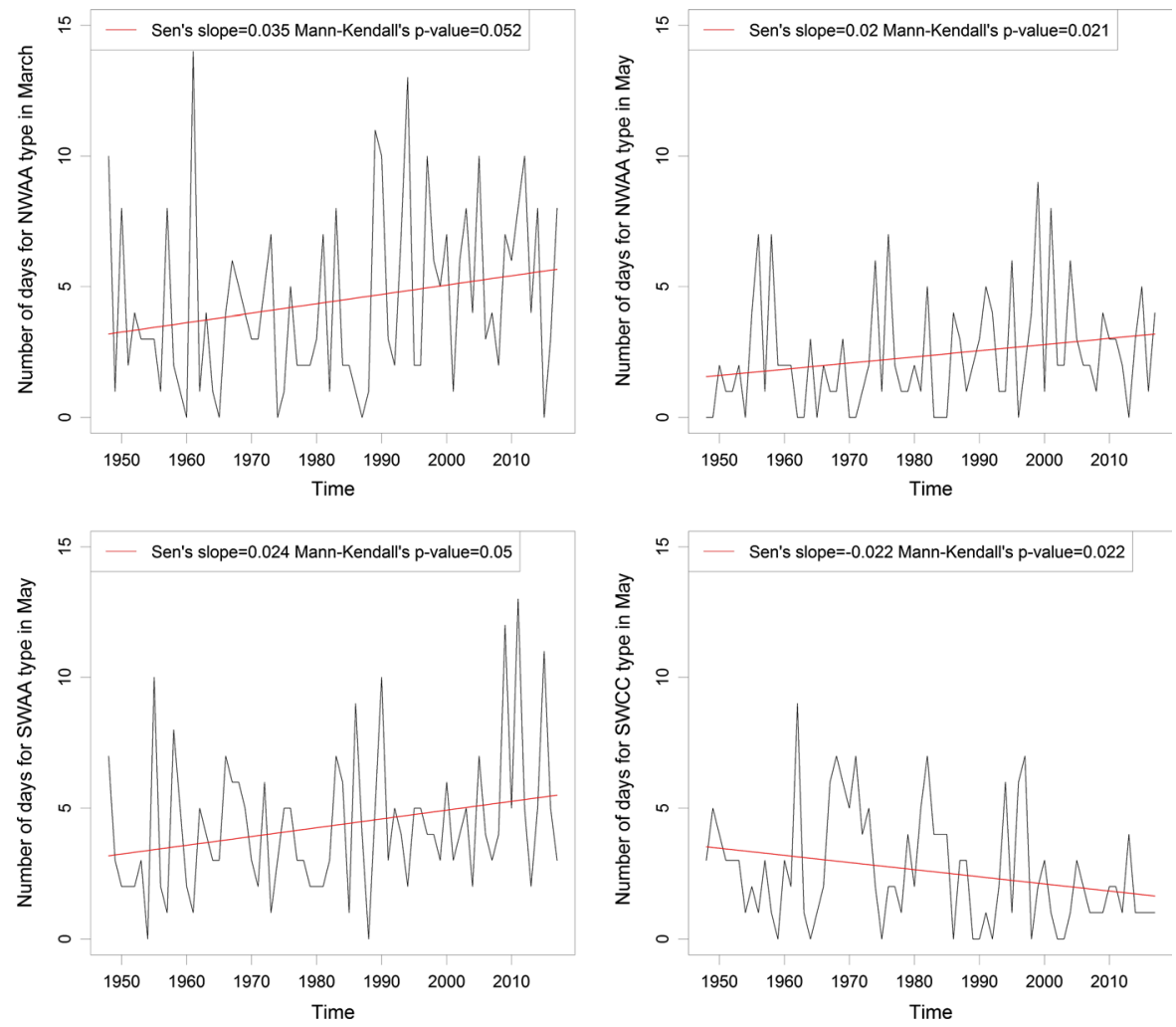

the period of 1871-2010. A direct comparison is impossible because of differences in the applied circulation types' classifications; however, Bartoszek (2017) has also shown an increasing tendency towards anticyclonic types' occurrence, which is indicated in this work as favourable to high Alnus and Betula concentrations. Still, studies by Hanewinkel et al. (2012) or Dyderski et al. (2017) have come to the conclusion of a decrease in the distribution range of birch. A suitable habitat area in Poland is dwindling due to climate change, which could limit pollen concentration. This situation is not so clear for Alnus (Sakalli 2017) but indisputably affects the results of our study. The observed increasing frequency of circulation types favouring a high pollen concentration concerns the last 70 years and is relatively weak ( 1 day in every 10 years). The analysed pollen seasons concern only the last 10-year period that is why there is no clear trend towards SPIn increase, as could be expected due to the increasing frequency of circulation types favouring high pollen concentrations.

The findings of this work support some of the earlier results from studies undertaken with different methods, e.g. analysis of backward trajectories. The analysis of circulation types brings some more insights to the understanding of pollen concentration in Central Europe. The method could be further applied to pollen-climate changes-related studies, e.g. future changes in the frequency of circulation types while taking into account the changing pollen distribution range. Recent findings presented by Rohrer et al. (2017) for the Alpine region have shown that the frequency of circulation types favourable to westerly flows and connected with higher temperature and humidity will increase in the spring until the end of the twenty-first century. Similar analysis with the method applied here could provide information about the trend of allergic pollen concentration over Central Europe.

\section{Summary and conclusion}

In this study, the influence of atmospheric circulation conditions, as described by specific circulation types, on Alnus and Betula pollen concentrations in Wroclaw, Poland, was analysed for the period from 2005 to 
2014. The results show that pollen concentrations vary significantly according to circulation types. The main findings of this work are the following:

1. The highest pollen concentrations for both Alnus and Betula are observed for warm, sunny, and dry anticyclonic circulation types with anticyclone in the lower and upper troposphere, especially for types with advection from SW. The lowest pollen concentrations are observed for cold, wet, and cloudy cyclonic types with advection from the northern sectors.

2. Sunshine duration could additionally influence pollen concentration (for both Alnus and Betula) regardless of the conditions connected with specific circulation types.

3. Apart from changes in the daily pollen concentration, the influence of circulation types could be noticeable in SPIn as well. There are some significant correlations between the SPIn of both Betula and Alnus and the frequency of specified circulation types.

4. Positive and statistically significant trends in the frequency of circulation types favourable for high concentrations of Betula and Alnus were shown for the last 70 years (1948-2017).

5. The method used here is flexible in terms of application to other geographical areas and different gridded meteorological data.

Acknowledgements NCEP reanalysis data provided by the NOAA/OAR/ESRL PSD, Boulder, Colorado, USA, from their website at http://www.esrl.noaa.gov/psd/. This study was supported by the Polish National Science Centre (Project Nos. UMO-2017/25/N/ST10/0049 and UMO-2017/25/B/ST10/ 00926).

Open Access This article is licensed under a Creative Commons Attribution 4.0 International License, which permits use, sharing, adaptation, distribution and reproduction in any medium or format, as long as you give appropriate credit to the original author(s) and the source, provide a link to the Creative Commons licence, and indicate if changes were made. The images or other third party material in this article are included in the article's Creative Commons licence, unless indicated otherwise in a credit line to the material. If material is not included in the article's Creative Commons licence and your intended use is not permitted by statutory regulation or exceeds the permitted use, you will need to obtain permission directly from the copyright holder. To view a copy of this licence, visit http://creativecommons.org/licenses/by/4.0/.

\section{References}

Bartoszek, K. (2017). The main characteristics of atmospheric circulation over East-Central Europe from 1871 to 2010. Meteorology Atmospheric Physics. https://doi.org/10. 1007/s00703-016-0455-z.

Bergmann, K. C., Werchan, D., \& Zuberbier, M. M. (2008). The threshold value of Ambrosia pollen inducing acute nasal reactions is very low. Allergology, 17, 375-376.

Bilińska, D., Skjøth, C. A., Werner, M., Kryza, M., Malkiewicz, M., Krynicka, J., et al. (2017). Source regions of ragweed pollen arriving in south-western Poland and the influence of meteorological data on the HYSPLIT model results. Aerobiologia. https://doi.org/10.1007/s10453-017-9471-9.

Bińkowska, I., Szopińska, E., Jaworek, J., \& Wierzcholska, S. (2013). Leksykon zieleni Wrocławia. Wrocław: Via Nova.

Bogawski, P., Borycka, K., Grewling, L., \& Kasprzyk, I. (2019). Detecting distant sources of airborne pollen for Poland: Integrating back-trajectory and dispersion modelling with a satellite-based phenology. Science of the Total Environment. https://doi.org/10.1016/j.scitotenv.2019.06.348.

Campbell, G. S., \& Norman, J. M. (1998). Environmental biophysics. New York: Springer.

Dahl, A., \& Strandhede, S. O. (1996). Predicting the intensity of the birch pollen season. Aerobiologia, 12, 97-106.

de Weger, L. A., Pashley, C. H., Šikoparija, B., Skjøth, C. A., Kasprzyk, I., Grewling, Ł., et al. (2016). The long distance transport of airborne Ambrosia pollen to the UK and the Netherlands from Central and south Europe. International Journal of Biometeorology. https://doi.org/10.1007/ s00484-016-1170-7.

Dosio, A., \& Paruolo, P. (2011). Bias correction of the ENSEMBLES high-resolution climate change projections for use by impact models: Evaluation on the present climate. Journal of Geophysical Research: Atmospheres, 116, 16.

Dyderski, M. K., Paź, S., Frelich, L. E., \& Jagodziński, A. M. (2017). How much does climate change threaten European forest tree species distribution? Global Change Biology, 24(3), 1150-1163.

Faegri, K., \& Iversen, J. (1989). Textbook of pollen analysis. London: Wiley.

Galán, C., Smith, M., Thibaudon, M., Frenguelli, G., Oteros, J., Gehrig, R., et al. (2014). Pollen monitoring: Minimum requirements and reproducibility of analysis. Aerobiologia. https://doi.org/10.1007/s10453-014-9335-5.

Glass, G. V., Peckham, P. D., \& Sanders, J. R. (1972). Consequences of failure to meet assumptions underlying fixed effects analyses of variance and covariance. Review of Educational Research, 42, 237-288.

Głowicki, B., Otop, I., Urban, G., \& Tomczyński, K. (2005). Klimat. Opracowanie ekofizjograficzne dla Województwa Dolnośląskiego. http://www.eko.wbu.wroc.pl/eko/index. php?option=com_frontpage\&Itemid=1. Accessed 07 March 2019.

Goyette-Pernot, J., Muñoz-Alpizar, R., Blanchet, J. P., Goyette, S., \& Beniston, M. (2003). Analysing ragweed pollen cloud over Montreal city center. In Proceedings of the 5th International Conference on Urban Climate, Lodz. 
Grewling, Ł., Jackowiak, B., Nowak, M., Uruska, M., \& Smith, M. (2012). Variations and trends of birch pollen seasons during 15 years (1996-2010) in relation to weather conditions in Poznan (western Poland). Grana, 51(4), 280-292.

Grundström, M., Dahl, Å., Ou, T., Chen, D., \& Pleijel, H. (2017). The relationship between birch pollen, air pollution and weather types and their effect on antihistamine purchase in two Swedish cities. Aerobiologia. https://doi.org/ 10.1007/s10453-017-9478-2.

Hanewinkel, M., Cullmann, D. A., Schelhaas, M. J., Nabuurs, G. J., \& Zimmermann, N. E. (2012). Climate change may cause sever loss in the economic value of European forest land. Nature Climate Change, 3(3), 203-207.

Hernández-Ceballos, M. A., Skjøth, C., García-Mozo, H., Bolívar, J. P., \& Galán, C. (2014). Improvement in the accuracy of back trajectories using WRF to identify pollen sources in southern Iberian Peninsula. International Journal of Biometeorology. https://doi.org/10.1007/s00484014-0804-x.

Kalnay, E., Kanamitsu, M., Kistler, R., Collins, W., Deaven, D., Gandin, L., et al. (1996). The NCEP/NCAR 40-Year Reanalysis Project. Bulletin of the American Meteorological Society, 77, 437-471.

Kasprzyk, I., Myszkowska, D., Grewling, Ł., Stach, A., Šikoparija, B., Skjøth, C. A., et al. (2011). The occurrence of Ambrosia pollen in Rzeszów, Kraków and Poznań, Poland: Investigation of trends and possible transport of Ambrosia pollen from Ukraine. International Journal of Biometeorology. https://doi.org/10.1007/s00484-0100376-3.

Kubik-Komar, A., Piotrowska-Weryszko, K., Weryszko-Chmielewska, E., Kuna-Broniowska, I., Chłopek, K., Myszkowska, D., et al. (2019). A study on the spatial and temporal variability in airborne Betula pollen concentration in five cities in Poland using multivariate analyses. Science of the Total Environment, 660, 1070-1078.

Lix, L. M., Keselman, J. C., \& Keselman, H. J. (1996). Consequences of assumption violations revisited: A quantitative review of alternatives to the one-way analysis of variance $F$ test. Review of Educational Research, 66, 579-619.

Makra, L., Sánta, T., Matyasovszky, I., Damialis, A., Karatzas, K., Bergmann, K. C., et al. (2010). Airborne pollen in three European cities: Detection of atmospheric circulation pathways by applying three dimensional clustering of backward trajectories. Journal of Geophysical Research. https://doi.org/10.1029/2010JD014743.

Malkiewicz, M., Klaczak, K., Drzeniecka-Osiadacz, A., Krynicka, J., \& Migała, K. (2014). Types of Artemisia pollen season depending on the weather conditions in Wrocław (Poland), 2002-2011. Aerobiologia. https://doi.org/10. 1007/s10453-013-9304-4.

Menut, L., Vautard, R., Colette, A., Khvorostyanov, D., Potier, A., Hamaoui-Laguel, L., et al. (2014). A new model of ragweed pollen release based on the analysis of meteorological conditions. Atmospheric Chemistry and Physics, Discussions. https://doi.org/10.5194/acpd-14-10891-2014.

Myszkowska, D., \& Piotrowicz, K. (2009). Birch (Betula L.) pollen seasons in Cracow in 1991-2008 in relation to meteorological conditions. Acta Agrobotanica, 62(2), 67-75.
Nowosad, J. (2015). Spatiotemporal models for predicting high pollen concentration level of Corylus, Alnus, and Betula. International Journal of Biometeorology. https://doi.org/ 10.1007/s00484-015-1077-8.

Nowosad, J., Stach, A., Kasprzyk, I., Latałowa, M., Puc, M., Myszkowska, D., et al. (2015). Temporal and spatiotemporal autocorrelation of daily concentrations of Alnus, Betula, and Corylus pollen in Poland. Aerobiologia, 31(2), 159-177.

Ojrzyńska, H. (2015). Cyrkulacyjne uwarunkowania przestrzennego rozkładu temperatury powietrza w terenie zróżnicowanym morfologicznie na przykładzie Sudetów. Rozprawy Naukowe Instytutu Geografii $i$ Rozwoju Regionalnego Uniwersytetu Wroctawskiego, 36, 228.

Ojrzyńska, H., Kryza, M., Wałaszek, K., Szymanowski, M., Werner, M., \& Dore, A. J. (2017). High resolution dynamical downscaling of ERA-Interim using the WRF regional climate model for the area of Poland. Part 2: Model performance with respect to automatically derived circulation types. Pure and Applied Geophysics. https:// doi.org/10.1007/s00024-016-1273-4.

Pacini, E., \& Hesse, M. (2004). Cytophysiology of pollen presentation and dispersal. Flora, 199, 273-285.

Puc, M., \& Kasprzyk, I. (2013). The patterns of Corylus and Alnus pollen seasons and pollination periods in two Polish cities located in different climatic regions. Aerobiologia. https://doi.org/10.1007/s10453-013-9299-x.

Puc, M., Wolski, T., Camacho, I. C., Myszkowska, D., Kasprzyk, I., Grewling, Ł., et al. (2015). Fluctuation of birch (Betula L.) pollen seasons in Poland. Acta Agrobotanica, 68(4), 303-313.

R Core Team. (2014). R: A language and environment for statistical computing. Vienna: R Foundation for Statistical Computing. http://www.R-project.org/.

Ranta, H., Kubin, E., Siljamo, P., Sofiev, M., Linkosalo, T., Oksanen, A., et al. (2006). Long distance pollen transport cause problems for determining the timing of birch pollen season in Fennoscandia by using phenological observations. Grana, 45, 297-304.

Rapiejko, P., Stankiewicz, W., Szczygielski, K., \& Jurkiewicz, D. (2007). Progowe stężenie pyłku roślin niezbędne do wywołania objawów alergicznych. Otolaryngologia Polska. https://doi.org/10.1016/S0030-6657(07)70491-2.

Ritenberga, O., Sofiev, M., Siljamo, P., Saarto, A., Dahl, A., Ekebom, A., et al. (2018). A statistical model for predicting the inter-annual variability of birch pollen abundance in Northern and North-Eastern Europe. Science of the Total Environment, 615, 228-239.

Rohrer, M., Croci-Maspoli, M., \& Appenzeller, Ch. (2017). Climate change and circulation types in Alpine region. Meteorologische Zeitschrift. https://doi.org/10.1127/metx/ 2016/0681.

Sakalli, A. (2017). Simulation of potential distribution and migration of Alnus spp. under climate change. Applied Ecology and Environmental Research, 15(4), 1039-1070.

Samoliński, B., Raciborski, F., Lipiec, A., Tomaszewska, A., Krzych-Fałta, E., Samel-Kowalik, P., et al. (2014). Epidemiologia Chorób Alergicznych w Polsce (ECAP). Alergologia Polska. https://doi.org/10.1016/j.alergo.2014. 03.008. 
Skjøth, C. A., Bilińska, D., Werner, M., Malkiewicz, M., Adams-Groom, B., Kryza, M., et al. (2015a). Footprint areas of pollen from alder (Alnus) and birch (Betula) in the UK (Worcester) and Poland (Wroclaw) during 2005-2014. Acta Agrobotanica. https://doi.org/10.5586/aa.2015.044.

Skjøth, C. A., Geels, C., Hvidberg, M., Hertel, O., Brandt, J., Frohn, L. M., et al. (2008). An inventory of tree species in Europe-An essential data input for air pollution modelling. Ecological Modelling. https://doi.org/10.1016/j. ecolmodel.2008.06.023.

Skjøth, C. A., Šikoparija, B., \& Jäger, S. (2013). Pollen sources. In M. Sofiev \& K. C. Bergmann (Eds.), Allergenic pollen. Dordrect: Springer. https://doi.org/10.1007/978-94-0074881-1_2.

Skjøth, C. A., Sommer, J., Stach, A., Smith, M., \& Brandt, J. (2007). The long-range transport of birch (Betula) pollen from Poland and Germany causes significant pre-season concentrations in Denmark. Clinical and Experimental Allergy. https://doi.org/10.1111/j.1365-2222.2007.02771. $\mathrm{x}$.

Skjøth, C. A., Werner, M., Kryza, M., Adams-Groom, B., Wakeham, A., Lewis, M., et al. (2015b). Quality of the governing temperature variables in WRF in relation to simulation of primary biological aerosols. Advances in Meteorology. https://doi.org/10.1155/2015/412658.

Smith, M., Skjøth, C. A., Myszkowska, D., Uruska, A., Puc, M., Stach, A., et al. (2008). Long-range transport of Ambrosia pollen to Poland. Agricultural and Forest Meteorology. https://doi.org/10.1016/j.agrformet.2008.04.005.
Sofiev, M., Siljamo, P., Ranta, H., \& Linkosalo, T. (2013). A numerical model of birch pollen emission and dispersion in the atmosphere. Description of the emission module. International Journal of Biometeorology. https://doi.org/10. 1007/s00484-012-0532-z.

Stach, A., Smith, M., Skjøth, C. A., \& Brandt, J. (2007). Examining Ambrosia pollen episodes at Poznań (Poland) using back-trajectory analysis. International Journal of Biometeorology. https://doi.org/10.1007/s00484-0060068-1.

Traidl-Hoffmann, C., Kasche, A., Menzel, A., Jakob, T., Thiel, M., Ring, J., et al. (2003). Impact of pollen on human health: More than allergen carriers? International Archives of Allergy and Immunology. https://doi.org/10.1159/ 000070428.

Tseng, Y. T., Kawashima, S., Kobatasji, S., Takeuchi, S., \& Nakamura, K. (2020). Forecasting the seasonal pollen index by using a hidden Markov model combining meteorological and biological factors. Science of the Total Environment, 698, 124246.

Veriankaite, L., Siljamo, P., Sofiev, M., Sauliene, I., \& Kukkonen, J. (2010). Modelling analysis of source regions of long-range transported birch pollen that influences allergenic seasons in Lithuania. Aerobiologia, 26, 47-62. https://doi.org/10.1007/s10453-009-9142-6.

Weryszko-Chmielewska, E., Puc, M., \& Piotrowska, K. (2006). Effect of meteorological factors on Betula, Fraxinus and Quercus pollen concentrations in the atmosphere of Lublin and Szczecin, Poland. Annals of Agricultural and Environmental Medicine, 13(2), 243-249. 